\title{
Willingness to Pay for Improved Water Supply Services Based on Asset Management: A Contingent Valuation Study in South Korea
}

\author{
Taehyeon Kim $^{+}{ }^{\mathbb{D}}$, Jihoon Shin ${ }^{\dagger}$, Jinseok Hyung, Kibum Kim, Jayong Koo and YoonKyung Cha *D \\ School of Environmental Engineering, University of Seoul, Seoul 02504, Korea; kimth0712@uos.ac.kr (T.K.); \\ sjh3473@uos.ac.kr (J.S.); gudwlstjr@uos.ac.kr (J.H.); kumbo88@uos.ac.kr (K.K.); jykoo@uos.ac.kr (J.K.) \\ * Correspondence: ykcha@uos.ac.kr \\ + Co-first authors.
}

Citation: Kim, T.; Shin, J.; Hyung, J.; Kim, K.; Koo, J.; Cha, Y. Willingness to Pay for Improved Water Supply Services Based on Asset Management: A Contingent Valuation Study in South Korea. Water 2021, 13, 2040. https://doi.org/10.3390/w13152040

Academic Editors: Sathaa Sathasivan and Armando Di Nardo

Received: 7 June 2021

Accepted: 22 July 2021

Published: 26 July 2021

Publisher's Note: MDPI stays neutral with regard to jurisdictional claims in published maps and institutional affiliations.

Copyright: (c) 2021 by the authors. Licensee MDPI, Basel, Switzerland. This article is an open access article distributed under the terms and conditions of the Creative Commons Attribution (CC BY) license (https:// creativecommons.org/licenses/by/ $4.0 /)$.
Abstract: The pressure on water infrastructure has increased due to an increase in the number of aging water pipes. Aging pipes are prone to failure, causing significant financial losses and service disruptions. The increasing number of aged pipes and limited budget for pipe rehabilitation or replacement necessitates water infrastructure asset management to ensure sustainable water supply services. In this study, contingent valuation was used to estimate the willingness to pay (WTP) and value improved water supply services through the implementation of asset management. To estimate the WTP at the individual and county levels, we performed a nationwide survey including eight provinces and 24 counties/cities with distinct water supply service performances. At the individual level, the median WTP estimated using the double-bounded dichotomous choice model was $249.50 \mathrm{KRW} /$ month (0.22 USD/month). The results showed that high-level satisfaction of customers with water supply services and positive price perception of water bills resulted in a high WTP. At the county level, decreasing water supply service performances were associated with a low WTP, indicating that proper interventions by local utilities are required to achieve sustainable water supply services. Our results provide a quantitative basis for decision-making in implementation of water infrastructure asset management.

Keywords: water infrastructure; asset management; water supply service; contingent valuation; willingness to pay

\section{Introduction}

Water pipe infrastructure provides potable water to people and thus plays an essential role in maintaining the socioeconomic status and quality of life [1-3]. However, despite its significance, water infrastructure has received increasing pressure from a variety of stressors, such as an increasing demand, climate change, and most noticeably, aging infrastructure $[2,4]$. Aging water pipes are prone to failure, leading to significant consequences, such as water loss, service disruptions, and damages to infrastructure and adjacent property [5,6], which all affect the economy. An increase in pipe failure due to aging has been reported in developed countries. In the United States and Canada, the pipe break rates increased by 27\% from 11.0 to 14.0 breaks /100 mi/year between 2012 and 2018 [7]. The replacement costs in the United States were estimated to increase from $\sim 13$ billion USD/year in 2010 to 30 billion USD/year by the 2040s [8]. In the United Kingdom, pipe failure associated with a water loss of 3 billion L/d will contribute to a $35 \%$ future increase in the water demand by 2050 [6].

In South Korea, rapid economic growth in the 1960s accelerated the construction of water infrastructure, with an increase in public water supply use from $16.8 \%$ in 1960 to $99.3 \%$ in 2019 [9,10]. Therefore, a significant number of water pipes in South Korea have reached the end of their lifespan. The numbers of reported pipe breaks and associated 
service disruptions have increased, resulting in a water loss of 690 million $\mathrm{t} /$ year, which is equivalent to 600 billion KRW (1115.7 KRW = 1 USD). Furthermore, $~ 33 \%$ of the water pipes in South Korea are expected to deteriorate within the next decade [10]. The deterioration due to aging adds repair and maintenance costs to the water production cost, negatively affecting the cost of recovery $[9,10]$. Consequently, investments into infrastructure by public water suppliers for maintenance, particularly by low-level local governments such as counties and cities, become less feasible. To overcome these problems, a national financing program has been implemented in 2017, which supports local water utilities in the renewal of water infrastructure [11].

However, the program has a limited budget. Although $\sim 2.4$ trillion KRW are invested in local water utilities over a 12-year span based on the national financing program, more than 18 trillion KRW are required to rehabilitate or replace all aging water pipes [12]. Furthermore, improving the maintenance of the water supply infrastructure by local water utilities based on national subsidies does not ensure the sustainability of the water infrastructure and supply services. To address these limitations, the national financing program requires local water utilities to implement water infrastructure asset management [11]. Asset management is a decision-making system in which infrastructure assets are managed based on risk assessment over their entire service life cycle to meet the level of service required by customers at the minimum cost $[1,2,13]$. Therefore, the adoption of asset management will enable local water utilities to operate and manage water infrastructure based on data-driven risk assessment to satisfy customer requirements while establishing a long-term funding strategy for the provision of sustainable and affordable water supply services [2].

Although asset management would lead to a shift from post to predictive maintenance, it is necessary to assess whether the benefits of asset management implementation exceed its costs considering the limited financial budget $[14,15]$. The benefits of asset management implementation can be divided into direct and indirect benefits $[16,17]$. Direct benefits include measurable cost reductions achieved by a decrease in water loss, repair to damage, and service disruptions. In contrast, indirect benefits are associated with improved customer satisfaction in response to the improved level of service $[14,16,18]$. However, because customer satisfaction is a non-use value that is not revealed in market prices, indirect benefits can be measured as customers' willingness to pay (WTP), which is determined using non-market valuation methods, such as contingent valuation (CV). Therefore, $\mathrm{CV}$ was used in this study to estimate the economic value of an improved service level based on water infrastructure asset management practices.

The CV method has been applied in a variety of environmental studies: valuation of project implementation for improved air quality [19], improved water quality [20], protection of coastal ecosystems improvement projects [21,22], and water quality protection $[20,23,24]$. In previous studies relevant to infrastructure management, CV was used to estimate the WTP for a stable water supply to prevent supply suspensions [25-27] and for the provision of safe drinking water $[28,29]$. In the present study, the WTP was estimated at the individual and county (or city) levels to provide a quantitative basis for prioritizing and allocating national subsidies for the implementation of water infrastructure asset management. We conducted a nationwide survey including 24 counties/cities in all eight provinces. Based on this wide spatial coverage, despite considerable efforts and costs involved in the survey, the effects of the water supply service performances of local utilities on the WTP could be revealed. Therefore, this study provides guidelines for long-term national planning for the implementation of water infrastructure asset management and local utility management plans, including water rate settings.

\section{Materials and Methods}

\subsection{Contingent Valuation}

Contingent valuation (CV) was used for the valuation of an improvement in the water supply services based on the adoption of a water infrastructure asset management system. 
A stated preference approach can be used to estimate the non-use value, for example, the preference for environmental quality, for cases in which revealed preferences from a real marketplace cannot be acquired [30]. CV is a commonly used stated preference approach wherein a hypothetical marketplace is established, and a survey designed and conducted to determine peoples' WTP for using a good or service [30-33]. Among different $\mathrm{CV}$ approaches, the double-bounded dichotomous choice (DBDC) model was used in this study to determine the WTP. Based on DBDC CV, a respondent is asked whether he/she would pay the given bid price for a good or service. Furthermore, the DBDC CV consists of two rounds of bidding and raises the second bid if the response to a randomly assigned initial bid is positive and vice versa. Compared with the single-bounded dichotomous choice model in which a single question is posed to the respondent, the DBDC model provides a follow-up question, which reduces the variance in the WTP estimates [34].

\subsection{Survey Sites and Samples}

Among 161 local governments in South Korea, 103 counties and cities are advised to adopt the water infrastructure asset management system as a follow-up measure in implementing the aging pipelines replacement program [11]. In this study, 24 counties and cities (three for each of the eight provinces) were selected as survey sites (Figure 1 and Table 1). They exhibit a wide range of water supply service performances including the annual number of water supply suspension accidents, the annual number of civil complaints, water production cost $\left(\mathrm{KRW} / \mathrm{m}^{3}\right)$, average water rate $\left(\mathrm{KRW} / \mathrm{m}^{3}\right)$, public water supply use (\% of the population), and cost recovery (\%) [35].

The survey was conducted via personal interviews, which yielded the most reliable WTP data, during 3-30 December 2018. Interviewers were experienced and were trained during the pretest period. Prior to the interview, interviewers explained the concept and necessity of the water infrastructure asset management system. As an incentive for accepting the request for an interview, the respondents received gift cards. In each of the 24 counties and cities, 40 randomly selected persons aged 20 years or older were surveyed. A total of 960 responses were collected. In addition, the 960 respondents were obtained not by pre-selecting 40 households by survey sites, but by continually randomly visiting households until 40 households in each of the 24 survey sites responded to the survey and provided an answer to the survey.

\subsection{Survey Design}

The survey for estimating the WTP in response to improved water services consisted of the purpose description and three sections of questions (Table 2). The first section included questions that accounted for the respondents' perceptions or attitude about the current level of water services. In the second section, CV questions in the DBDC format were asked to measure the respondents' WTP for improved water services. The follow-up questions asked how the increased water bill generated as a result of the WTP valuation should be distributed among the three desired outcomes: prevention of water supply suspension, improved water quality, and improved customer services. The questions in the third section were asked to collect sociodemographic information about the respondents.

In the CV questionnaire, an additional charge for $1 \mathrm{~m}^{3}$ water use was used as the payment vehicle. Accordingly, the respondents were asked if they were willing to pay the additional charge provided that the adoption of water infrastructure asset management leads to service improvement. The CV question about the WTP the initial bid $\left(\mathrm{BID}_{1}\right)$ was as follows: "If the adoption of water infrastructure asset management leads to the prevention of water supply suspension and improved water quality in your house as well as improved customer services, are you willing to pay $\mathrm{BID}_{0} \mathrm{KRW}$ in addition to the current monthly water bill?" To mitigate hypothetical bias, reference information was provided including the average monthly water bill per capita for the respondent's county/city of residence [36]. The second-round bid $\left(\mathrm{BID}_{2}\right)$ was doubled and halved when the answer the question about the WTP the initial bid was "yes" and "no," respectively. The use of the DBDC model 
might lead to a starting point bias, which refers to the effect of the initial bid price on the respondent's WTP estimate [37]. To avoid this type of bias, a set of initial bids, that is, 10, $20,30,40$, and 50, was suggested based on the results of the pretest and expert consultation. Within each county/city, the set of initial bids with an equal assignment probability was randomly assigned to the respondents.

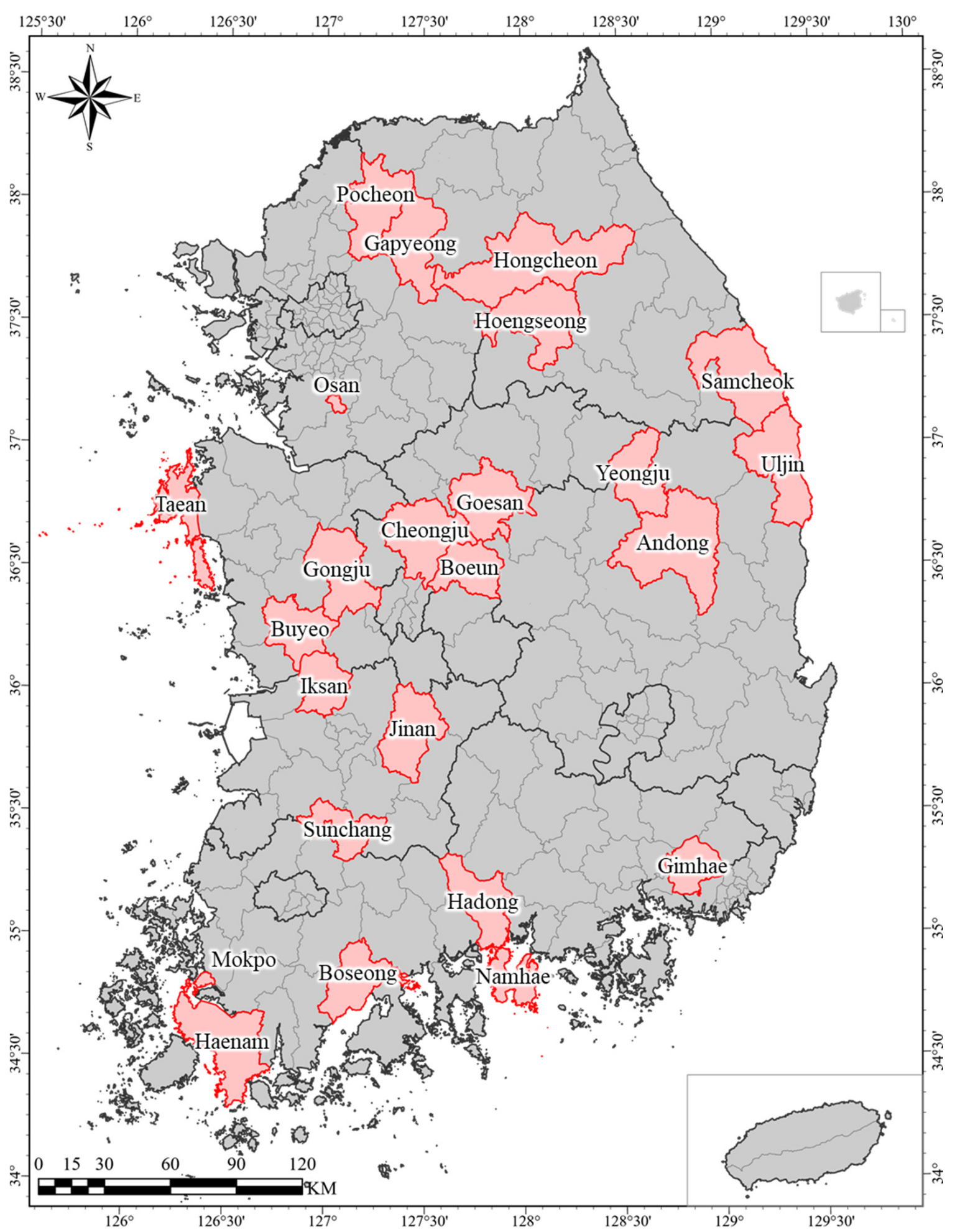

Figure 1. Survey sites (24 counties/cities) in South Korea. 
Table 1. Water supply service performance indicators for 24 survey sites in South Korea (1115.7 KRW = 1 USD).

\begin{tabular}{|c|c|c|c|c|c|c|c|}
\hline Province & City/County & $\begin{array}{l}\text { No. of Water } \\
\text { Supply } \\
\text { Suspension } \\
\text { Accidents }\end{array}$ & $\begin{array}{l}\text { No. of Civil } \\
\text { Complaints }\end{array}$ & $\begin{array}{c}\text { Water } \\
\text { Production } \\
\text { Cost } \\
\left(\mathrm{KRW} / \mathrm{m}^{3}\right)\end{array}$ & $\begin{array}{c}\text { Average Water } \\
\text { Rate } \\
\left(\mathrm{KRW} / \mathrm{m}^{3}\right)\end{array}$ & $\begin{array}{l}\text { Public Water } \\
\text { Supply Use } \\
\text { (as \% of } \\
\text { Population) }\end{array}$ & $\begin{array}{c}\text { Cost Recovery } \\
(\%)\end{array}$ \\
\hline \multirow[t]{3}{*}{ Gyeonggi } & Osan & 30 & 2145 & 723.0 & 613.69 & 100.0 & 84.88 \\
\hline & Pocheon & 90 & 2383 & 1701.0 & 1006.72 & 89.2 & 59.18 \\
\hline & Gapyeong & 50 & 596 & 2626.0 & 1291.62 & 89.0 & 49.19 \\
\hline \multirow[t]{3}{*}{ Gangwon } & Samcheok & 2 & 683 & 1722.0 & 1202.20 & 100.0 & 69.81 \\
\hline & Hongcheon & 10 & 451 & 2488.0 & 1548.61 & 81.3 & 62.24 \\
\hline & Hoengseong & 52 & 4183 & 2977.1 & 1197.95 & 89.3 & 40.24 \\
\hline \multirow[t]{3}{*}{ Chungcheongbuk } & Cheongju & 149 & 24954 & 745.4 & 646.06 & 99.5 & 86.67 \\
\hline & Boeun & 25 & 344 & 1792.0 & 754.59 & 97.7 & 42.11 \\
\hline & Goesan & 24 & 172 & 2390.0 & 970.29 & 96.5 & 40.60 \\
\hline \multirow[t]{3}{*}{ Chungcheongnam } & Taean & 116 & 696 & 3125.0 & 1023.92 & 87.6 & 32.77 \\
\hline & Gongju & 23 & 3072 & 1839.0 & 774.66 & 96.2 & 42.11 \\
\hline & Buyeo & 186 & 1488 & 2182.8 & 841.97 & 92.6 & 38.57 \\
\hline \multirow[t]{3}{*}{ Joellabuk } & Iksan & 231 & 2685 & 905.0 & 759.68 & 99.4 & 83.94 \\
\hline & Sunchang & 4 & 980 & 1520.0 & 897.64 & 96.2 & 59.06 \\
\hline & Jinan & 33 & 363 & 3600.0 & 765.72 & 96.3 & 21.27 \\
\hline \multirow[t]{3}{*}{ Joellanam } & Mokpo & 0 & 6778 & 788.2 & 712.58 & 100.0 & 90.41 \\
\hline & Boseong & 36 & 315 & 940.0 & 805.29 & 96.4 & 85.67 \\
\hline & Haenam & 0 & 125 & 1083.0 & 952.90 & 95.7 & 87.99 \\
\hline \multirow[t]{3}{*}{ Gyeongsangbuk } & Andong & 81 & 6544 & 1575.3 & 888.95 & 99.5 & 56.43 \\
\hline & Uljin & 45 & 1058 & 3184.5 & 783.13 & 94.5 & 24.59 \\
\hline & Yeongju & 118 & 2688 & 1504.8 & 1027.49 & 97.7 & 68.28 \\
\hline \multirow[t]{3}{*}{ Gyeongsangnam } & Gimhae & 1250 & 7958 & 1042.0 & 854.58 & 98.8 & 82.01 \\
\hline & Hadong & 161 & 344 & 1374.4 & 807.55 & 100.0 & 58.76 \\
\hline & Namhae & 120 & 1350 & 2144.0 & 891.63 & 100.0 & 41.59 \\
\hline
\end{tabular}

Table 2. Variable definition and descriptive statistics.

\begin{tabular}{|c|c|c|c|c|}
\hline Variable & Description & Obs. & Mean & S.D. \\
\hline AGE & Age of respondents & 704 & 42.97 & 13.01 \\
\hline GENDER & Gender of respondents: 0 male; 1 female & 704 & 0.61 & 0.49 \\
\hline Occupation1 & 1 if your occupation is an administrator, professional or clerk; 0 Otherwise & 704 & 0.35 & 0.48 \\
\hline Occupation2 & $\begin{array}{l}1 \text { if your occupation is a service worker, sales worker, skilled agricultural, } \\
\text { forestry and fishery worker, craft and related trade worker, plant, machine } \\
\text { operator and assembler or elementary worker; } 0 \text { Otherwise }\end{array}$ & 704 & 0.44 & 0.50 \\
\hline Occupation 3 & $\begin{array}{l}1 \text { if your occupation is a student (including people in military service), } \\
\text { housewife or unemployed (including retirement); } 0 \text { Otherwise }\end{array}$ & 704 & 0.18 & 0.39 \\
\hline DRINK & 1 if drinking (boiled) tap water; 0 Otherwise & 704 & 0.70 & 0.46 \\
\hline P_BILL & $\begin{array}{l}\text { How expensive is the monthly water bill for you? (1. Very expensive; } 2 \text {. } \\
\text { Expensive; } 3 \text {. Affordable; } 4 \text {. Cheap; } 5 \text {. Very cheap) }\end{array}$ & 651 & 2.77 & 0.63 \\
\hline SAT_QUAN & $\begin{array}{l}\text { How satisfied are you with the tap flow rate? (1. Very dissatisfied; } 2 \text {. } \\
\text { Dissatisfied; } 3 \text {. Neither dissatisfied nor satisfied; } 4 \text {. Satisfied; } 5 \text {. Very satisfied) }\end{array}$ & 686 & 3.93 & 0.87 \\
\hline SAT_PRES & $\begin{array}{l}\text { How satisfied are you with the tap pressure? (1. Very dissatisfied; } 2 \text {. } \\
\text { Dissatisfied; } 3 \text {. Neither dissatisfied nor satisfied; } 4 \text {. Satisfied; } 5 \text {. Very satisfied) }\end{array}$ & 693 & 3.64 & 0.95 \\
\hline SAT_QUAL & $\begin{array}{l}\text { How satisfied are you with the quality of the tap water? (1. Very dissatisfied; } 2 \text {. } \\
\text { Dissatisfied; } 3 \text {. Neither dissatisfied nor satisfied; } 4 \text {. Satisfied; } 5 \text {. Very satisfied) }\end{array}$ & 662 & 3.55 & 0.87 \\
\hline SAT_AES & $\begin{array}{c}\text { How satisfied are you with the aesthetic aspects (taste/odor/color, etc.) of the } \\
\text { tap water? (1. Very dissatisfied; } 2 \text {. Dissatisfied; } 3 \text {. Neither dissatisfied nor } \\
\text { satisfied; } 4 \text {. Satisfied; } 5 \text {. Very satisfied) }\end{array}$ & 663 & 3.43 & 0.86 \\
\hline No_ACC & $\begin{array}{l}\text { How many times have you experienced water supply suspension accidents } \\
\text { within the past } 5 \text { years? (1. None; } 2 \text {. one to two; } 3 \text {. three to four; } 4 \text {. five or more) }\end{array}$ & 651 & 1.66 & 0.82 \\
\hline EXP_COMP & $\begin{array}{l}1 \text { if having experience with filing civil complaints in the past; } 0 \text { Otherwise } \\
\text { If having experience with filing civil complaints in the past, how satisfied are }\end{array}$ & 701 & 0.07 & 0.26 \\
\hline SAT_COMP & $\begin{array}{l}\text { you with the complaint handling? (1. Very dissatisfied; } 2 \text {. Dissatisfied; } 3 \text {. } \\
\text { Neither dissatisfied nor satisfied; } 4 \text {. Satisfied; } 5 \text {. Very satisfied) }\end{array}$ & 52 & 2.94 & 1.11 \\
\hline
\end{tabular}


Table 2. Cont.

\begin{tabular}{ccccc}
\hline Variable & Description & Obs. & Mean & S.D. \\
\hline Perc_SUS & What percentage of the increased revenue due to the increased water bill do & 616 & 33.53 & 16.34 \\
& you want to assign to prevent water suspension accidents? & & \\
Perc_WQ & What percentage of the increased revenue due to the increased water bill do & 616 & 47.40 & 18.41 \\
& you want to assign to improve water quality? & & & \\
Perc_SER & What percentage of the increased revenue due to the increased water bill do & 616 & 19.07 & 11.47 \\
Bid 1 & you want to assign to improve customer satisfaction of water services? & 704 & 29.32 & 14.53 \\
Bid 2 & The initial bid randomly assigned to respondents & 704 & 48.20 & 30.93 \\
\hline
\end{tabular}

Furthermore, to distinguish protest responses in the CV, respondents with "no-no" answers were required to identify the rationale for the zero WTP. Six choices explaining the respondent's zero WTP could be made: (1) poor economic condition; (2) low personal priority to water supply services; (3) little personal interest in water supply services; (4) improved water service required at the current water rate; (5) insufficient information provided to value improved water services; and (6) disbelief in local governments, which are supposed to use the raised public revenue for the improvement of water services. The responses of people who selected answer choices 4-6 were classified as protest zeros and were excluded from the WTP estimation [38]. Moreover, non-responses to any question in the questionnaire were excluded from the analysis.

\subsection{Model Development}

A utility difference approach was adopted to model the responses to the DBDC format [31,34]. Based on the DBDC format, the WTP of the additional charge in response to the adoption of water infrastructure asset management can be expressed as a function of the utility:

$$
u(j, y ; S)=v(j, y ; S)+\varepsilon_{j}
$$

The utility of a respondent $(u)$ can be divided into observable $(v)$ and unobservable $(\varepsilon)$ components. In Equation (1), $j$ indicates the status of water supply services, where $j=0$ denotes the current level of services and $j=1$ represents the improved level of services as a result of asset management implementation. The variable $y$ indicates the respondent's outcome, whereas $S$ is a vector that includes the respondent's sociodemographic characteristics and perceptions of the current level of water supply services. The mean of $\varepsilon$ is zero; $\varepsilon$ is assumed to be independent and randomly and identically distributed. The additional charge that is suggested as bid price $A$ can be paid when the following condition is met:

$$
v(1, y-A ; S)+\varepsilon_{1} \geq v(0, y ; S)+\varepsilon_{0}
$$

Accordingly, the probability that the respondent says "yes" to the bid price can be expressed as follows:

$$
\begin{gathered}
P_{1}=\operatorname{Pr}\{“ y e s "\}=\operatorname{Pr}\{A \leq \operatorname{maxWTP}\}=\operatorname{Pr}\left\{v(1, y-A ; s)+\varepsilon_{1} \geq v(0, y ; S)+\varepsilon_{0}\right\} \\
P_{0}=\operatorname{Pr}\left\{“ n o^{\prime \prime}\right\}=\operatorname{Pr}\{A>\max W T P\}=1-P_{1}
\end{gathered}
$$

where maxWTP is the maximum WTP. Based on the assumption of a log-logistic distribution, the probability of the answer being "yes" can be expressed as follows:

$$
\operatorname{Pr}\{A \leq \max W T P\}=1-1 /(1+\exp (a+\gamma S-b \ln (A))=1-G(A ; \theta),
$$

where $G(\cdot)$ represents the logistic distribution function and $\theta=\{a, \gamma, b\}$ is a parameter vector. In the DBDC format, four different combinations of answers to the CV questions can be given: (1) "yes-yes," (2) "yes-no," (3) "no-yes," and (4) "no-no". Herein, bid indicates a randomly assigned initial bid, and $b i d_{k}^{L}$ and $b i d_{k}^{U}$ indicate a lower and upper 
bid, respectively. The $b i d_{k}^{L}$ is selected when the answer to the $b i d_{k}^{I}$ is "no", and vice versa. The likelihood of the answers being "yes-yes" $\left(\pi^{y y}\right)$, where maxWTP is higher than bid ${ }_{i}^{U}$, can be expressed as follows [31,34]:

$$
\pi^{y y}\left(b i d_{k}^{I}, b i d_{k}^{U}\right)=\operatorname{Pr}\left\{b i d_{k}^{U} \leq \max W T P\right\}=1-G\left(b i d_{k}^{U} ; \theta\right)
$$

The likelihood of the answers being "yes-no" $\left(\pi^{y n}\right)$, where maxWTP is higher than $b_{i d}$ and lower than $b_{i d}^{U}$, can be expressed as follows:

$$
\pi^{y n}\left(b i d_{k}^{I}, b i d_{k}^{U}\right)=\operatorname{Pr}\left\{b i d_{k} \leq \max W T P \leq b i d_{k}^{U}\right\}=G\left(b i d_{k}^{U} ; \theta\right)-G\left(b i d_{k}^{I} ; \theta\right)
$$

The likelihood of the answers being "no-yes" and "no-no," denoted as $\pi^{n y}$ and $\pi^{n n}$, respectively, can be expressed as follows:

$$
\begin{aligned}
& \pi^{n y}\left(b i d_{k}^{I}, b i d_{k}^{L}\right)=\operatorname{Pr}\left\{b i d_{k}^{I} \geq \max W T P \geq \operatorname{bid}_{k}^{U}\right\}=G\left(b i d_{k}^{I} ; \theta\right)-G\left(b i d_{k}^{L} ; \theta\right) \\
& \pi^{n n}\left(b i d_{k}^{I}, b i d_{k}^{L}\right)=\operatorname{Pr}\left\{b i d_{k}^{U}>\max W T P \text { and } b i d_{k}^{L}>\max W T P\right\}=G\left(b i d_{k}^{L} ; \theta\right)
\end{aligned}
$$

By combining Equations (5)-(8), the log-likelihood function can be expressed as follows (Hanemann et al., 1991):

$$
\ln L=\sum_{k=1}^{N} d_{k}^{y y} \ln \pi^{y y}\left(b i d_{k}^{I}, b i d_{k}^{U}\right)+d_{k}^{y n} \ln \pi^{y n}\left(b i d_{k}^{I}, b i d_{k}^{U}\right)+d_{k}^{n y} \ln \pi^{n y}\left(b i d_{k}^{I}, b i d_{k}^{L}\right)+d_{k}^{n n} \ln \pi^{n n}\left(b i d_{k}^{I}, b i d_{k}^{L}\right),
$$

where $d_{k}^{y y}, d_{k}^{y n}, d_{k}^{n y}$, and $d_{k}^{n n}$ are the indicator functions. For example, when the answer is "yes-yes," the corresponding indicator, $d_{k}^{y y}$, has a value of 1 ; otherwise, its value is 0 . The WTP is estimated using the parameter that maximizes the log-likelihood function (Figure 2).

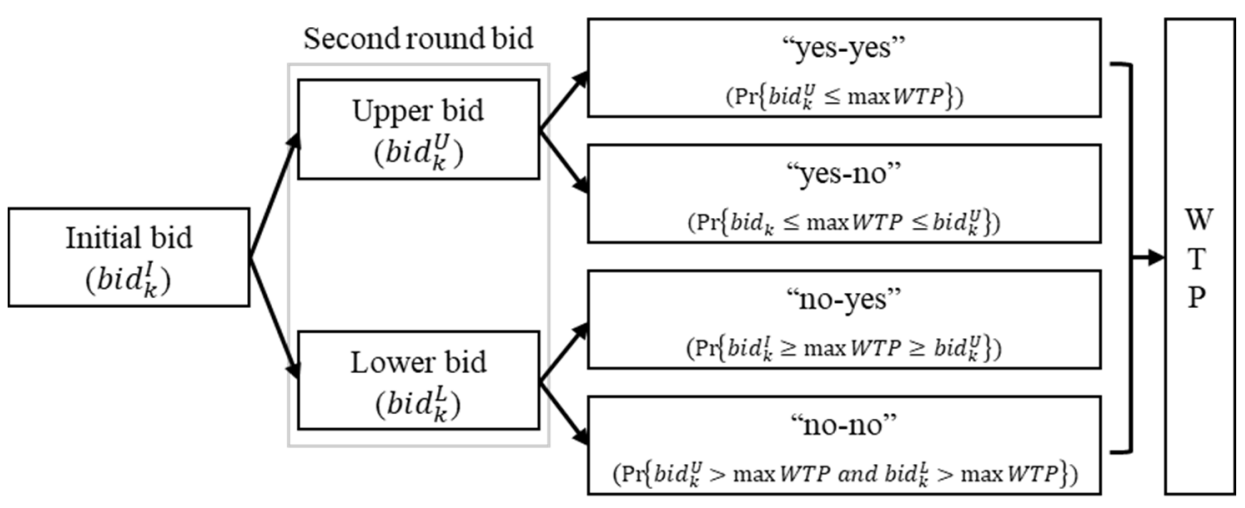

Figure 2. Flowchart of the DBDC model.

In this study, the WTP was estimated at both individual and county (or city) levels. At the individual level, the truncated mean WTP, median WTP, and Krinsky and Robb confidence interval [39] were estimated using the regression with covariates that accounted for individual characteristics, such as sociodemographic information (i.e., age, gender, and occupation), and the satisfaction level for each component of the water supply services (i.e., P_BILL, SAT_QUAN, SAT_PRES, SAT_QUAL, SAT_AES, No_ACC, and EXP_COMP). Moreover, the intercept-only model, which does not include any covariates, was used to estimate the WTP for each county/city. Furthermore, at the county level, the correlations between the factors that reflect water supply service performances and the WTP estimates were analyzed based on Pearson's correlation coefficients. Modeling and statistical analyses were performed using R 4.0.2 [40] and the "DCchoice" package was utilized for the WTP estimation [41]. 
Information about the sociodemographic background of the respondents, which was one of the covariates that might affect the WTP, included the age (AGE), gender (GENDER), and occupation (Occupation; Table 2). To assess public perceptions about the current level of water supply services and effects of perceptions on the WTP, the respondents were asked multiple questions for which the answer choices were provided based on the 5-point Likert scale (Table 2).

\section{Results and Discussion}

\subsection{Survey Results}

Among the 960 survey results, 39 non-responses to the $C V$ questionnaire and 217 protest zeros were excluded from the analyses. The average age of the 704 respondents who provided valid responses was 42.97 , and $60.51 \%$ and $39.49 \%$ were female and male, respectively. Occupations included office workers (Occupation1), production workers (Occupation2), and others, mainly housewives and students (including people in military service; Occupation3), accounting for $35.08 \%, 44.46 \%$, and $18.47 \%$ of the respondents, respectively.

When asked if a respondent drinks tap water or boiled tap water (DRINK), most responses $(70.31 \%)$ were positive, indicating the public trust in the safety of tap water. However, most of the respondents ( $87.07 \%$ of positive responses) also used a water purifier, bottled water, or other drinking water sources such as ground and spring water. Therefore, based on the inclusion of the negative responses $(29.69 \%)$, the majority of respondents were found to be considerably concerned about drinking tap water. The average price perception of the water bill (P_BILL) was slightly positive (mean value $=2.77$ ), with the majority of respondents (68.97\%) answering "affordable." Moreover, the satisfaction level regarding water supply services was determined based on the tap flow rate (SAT_QUAN), tap pressure (SAT_PRES), quality of tap water (SAT_QUAL), and aesthetics of tap water (SAT_AES; Table 2). Among five levels ranging from "very dissatisfied" to "very satisfied", the mean satisfaction levels for different service aspects ranged from 3.43 for aesthetics to 3.93 for quantity. The results indicated that customers were more satisfied with the quantity aspects (SAT_QUAN and SAT_PRES) than with the quality aspects (SAT_QUAL and SAT_AES). The next questions considered the personal experience, which might influence the perception of water supply services. In terms of the experience of water supply suspensions (No_ACC), most respondents (84.79\%) experienced zero to two water supply suspension accidents within the past five years. In addition, only $7 \%$ of the respondents had experience (EXP_COMP) with filing civil complaints related to water supply services. Among the 52 respondents who filed complaints, the satisfaction level for the complaint handling (SAT_COMP) was widely distributed, with $82.69 \%$ of the answers ranging between "dissatisfied" and "satisfied" (Figure 3).

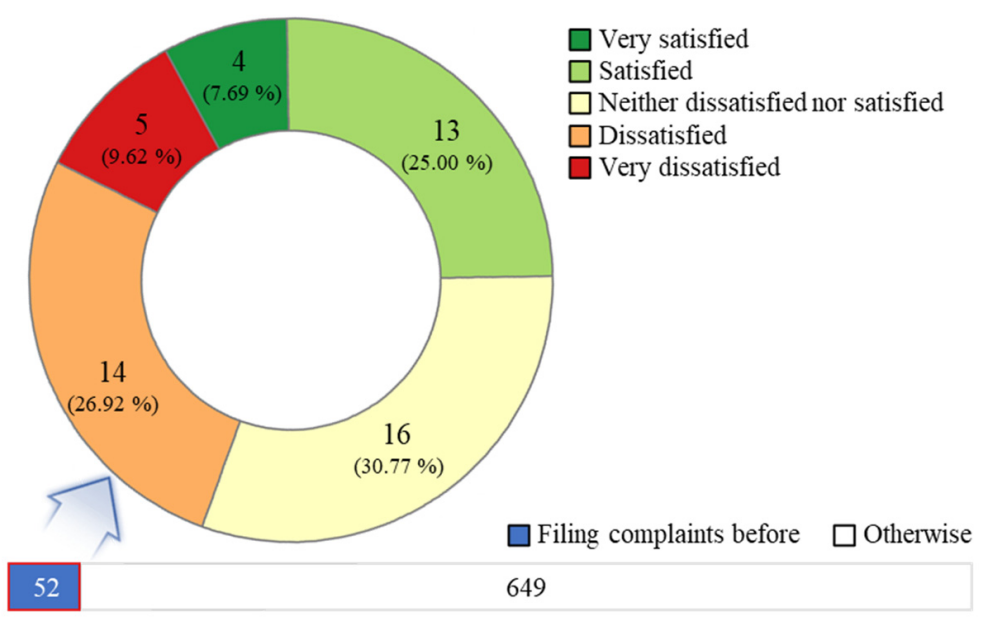

Figure 3. Detailed responses (total number) on the satisfaction level with respect to complaint handling. 


\subsection{Willingness-to-Pay at the Individual Level}

When asked about the WTP the initial bid $\left(\mathrm{BID}_{1}\right), 78.55 \%$ of the respondents answered "yes" ( $\mathrm{n}=553)$. For the second bid $\left(\mathrm{BID}_{2}\right), 51.72 \%$ of respondents who said "yes" for the initial bid answered "yes" ( $\mathrm{n}=286$ ) and $64.24 \%$ of those whose said "no" for the initial bid answered "yes" ( $n=97)$. Based on the combination of positive responses, either to the initial bid or to the second bid, almost all respondents (92.33\%) were willing to pay for improved water supply services based on asset management implementation. Based on the DBDC model, the truncated mean WTP was $54.41 \mathrm{KRW} / \mathrm{m}^{3}(1115.7 \mathrm{KRW}=1 \mathrm{USD})$, with a confidence interval ranging from 51.19-57.51. The median WTP was $48.33 \mathrm{KRW} / \mathrm{m}^{3}$, with a confidence interval ranging from 43.60-53.59 (Table 3). Furthermore, the increase in the monthly water bill per capita, which was calculated based on the WTP estimates that accounted for liters per capita per day (LPCD) for domestic supply for each local government, was 280.88 and $249.50 \mathrm{KRW} /$ month based on the truncated mean and median WTP, respectively.

Table 3. Individual-level willingness to pay (WTP) estimated using the double-bounded dichotomous choice (DBDC) model with covariates that account for sociodemographic characteristics and customer satisfaction.

\begin{tabular}{cc}
\hline Variable & Coefficient (S.E.) \\
\hline Intercept & $4.79^{* * *}(0.92)$ \\
AGE & $-0.02^{* *}(0.01)$ \\
GENDER & $0.06(0.17)$ \\
Occupation1 & $-0.18(0.58)$ \\
Occupation2 & $-0.30(0.57)$ \\
Occupation3 & $-0.67(0.59)$ \\
DRINK & $0.01(0.19)$ \\
P_BILL & $0.40^{* *}(0.14)$ \\
SAT_QUAN & $0.34^{* *}(0.13)$ \\
SAT_PRES & $-0.08(0.11)$ \\
SAT_QUAL & $-0.10(0.14)$ \\
SAT_AES & $0.19(0.13)$ \\
No_ACC & $0.10(0.11)$ \\
EXP_COMP & $-0.19(0.32)$ \\
log(bid) & $-1.63 * *(0.08)$ \\
\hline Mean WTP (truncated at maximum bid) & $54.41[51.19-57.51]^{1}$ \\
Median WTP & $48.33[43.60-53.59]^{1}$ \\
Obs. & 560 \\
Log-likelihood & -721.24 \\
AIC & 1472.47 \\
\hline
\end{tabular}

${ }^{1}$ Krinsky and Robb confidence interval; ${ }^{* *}$ for $p<0.01$, and ${ }^{* * *}$ for $p<0.001$.

Among the covariates in the DBDC model, two variables that reflected the public perception of water supply services (SAT_QUAN and P_BILLS) and one sociodemographic variable (AGE) had significant effects on the WTP estimation (Table 3). The positive slope of SAT_QUAN, which indicated the customer satisfaction in terms of the water quantity, was significant. Notably insignificant slopes for other covariates for the customer satisfaction (SAT_PRES, SAT_QUAL, and SAT_AES) might be due to moderate to strong positive correlations (0.43-0.65) between these variables and SAT_QUAN. In addition, positive correlations between all covariates for the customer satisfaction and WTP indicated that respondents who were satisfied with the current level of water supply services were willing to pay higher additional charges for further improvements. Moreover, the positive effect of P_BILLS on the WTP was significant, indicating that the WTP was higher for respondents who had positive price perceptions of the water bill. For those who had negative price perceptions, the resistance to pay additional charges may be due to the notion that government authorities, not individuals, should take responsibility for the management of the water supply that belongs to public goods [9]. Model results indicated 
that the WTP increased with decreasing age. A negative correlation between the WTP and age has been reported in previous studies $[28,29,42]$.

Furthermore, the respondents were asked how the increased revenue due to the increased water bill should be distributed among different services, that is, the water quantity (Perc_SUS), water quality (Perc_WQ), and customer satisfaction (Perc_SER; Table 2). Excluding non-responses, 616 respondents assigned, in increasing order of importance, an average of $47.40 \%$ to improved water quality, $33.53 \%$ to the prevention of water supply suspensions, and $19.07 \%$ to improved customer service (Figure 4). The higher value assigned to the water quality revealed that increased efforts would be required to improve the water quality compared with the water quantity, which is related to stability and sufficiency. In fact, the national average public water supply use approached $99.3 \%$ as of $2019[9,10]$, even though households in low-level governments had limited access to the public water supply (Table 2). Consistent with the survey results, an increased number of water quality-related civil complaints, such as high turbidity, bad odor, and bad taste, has been filed [43-45]. Therefore, to meet the public water quality requirements, the investments in advanced water treatment as well as in pipeline management, such as flushing and rehabilitation of corroded pipes, must be increased $[44,46]$.

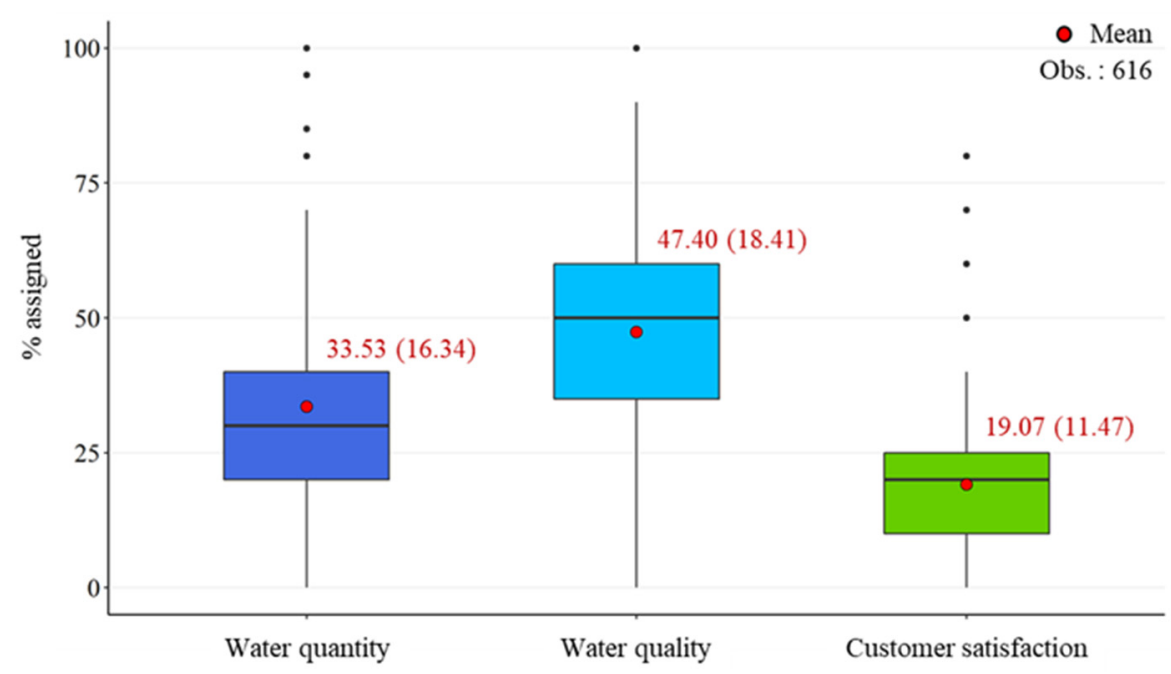

Figure 4. Respondents' willingness to assign increased revenue due to an increased water bill to different services: water quantity (Perc_SUS), water quality (Perc_WQ), and customer satisfaction (Perc_SER).

\subsection{Willingness-to-Pay at the County Level}

The WTP estimates for each county/city varied widely, with a truncated mean ranging between $29.54-70.05 \mathrm{KRW} / \mathrm{m}^{3}$ and a median ranging between $19.74-93.83 \mathrm{KRW} / \mathrm{m}^{3}$ (Figure S1). Notably, the mean and median WTP for Namhae County, which experienced severe drought and water shortage in 2017, were the highest among all surveyed local governments. Therefore, the high WTP estimates for Namhae might reflect the increased demand of the local residents for a stable water supply despite potentially recurring catastrophic events (Figure S1). This also indicated that an increase in stress due to climate change will likely increase the WTP for sustainable water supply services [47-49]. Furthermore, Figure 5 demonstrates that the large variability in the WTP may be attributed to different water supply performances among the surveyed local governments. Among the performance indicators for water supply services, the annual number of water supply suspensions and the annual number of civil complaints in 2018 were weakly correlated with the county-level WTP (Figure 5a,b). In contrast, the water production cost and rate were moderately negatively correlated with the WTP (Figure $5 \mathrm{c}, \mathrm{d}$ ), whereas the public water supply use was moderately, positively correlated with the WTP (Figure 5e). These correlations and the negative correlation $(\mathrm{r}=-0.58)$ between the water production cost and 
public water supply use indicated that difficulties in increasing the public water supply use (e.g., poor funding sources and sparse population density) led to an increase in the water production cost. High production costs that resulted from disadvantageous water supply conditions involved high water rates. Increasing water rates would possibly increase the local residents' negative price perceptions (expressed as P_BILLS at the individual level), which negatively affected their WTP (Table 3). In addition, high production costs contributed to reductions in the cost recovery (Figure 5f), preventing these local utilities from implementing required management measures in a timely manner. These results showed that, without national investments, sustainable water supply services could not be pursued by local utilities with low service performances. Therefore, the poorly performing utilities, which are destined to be in a vicious cycle of poor water supply services without proper interventions, should be highly prioritized during budget and financial planning for the adoption and implementation of water infrastructure asset management.
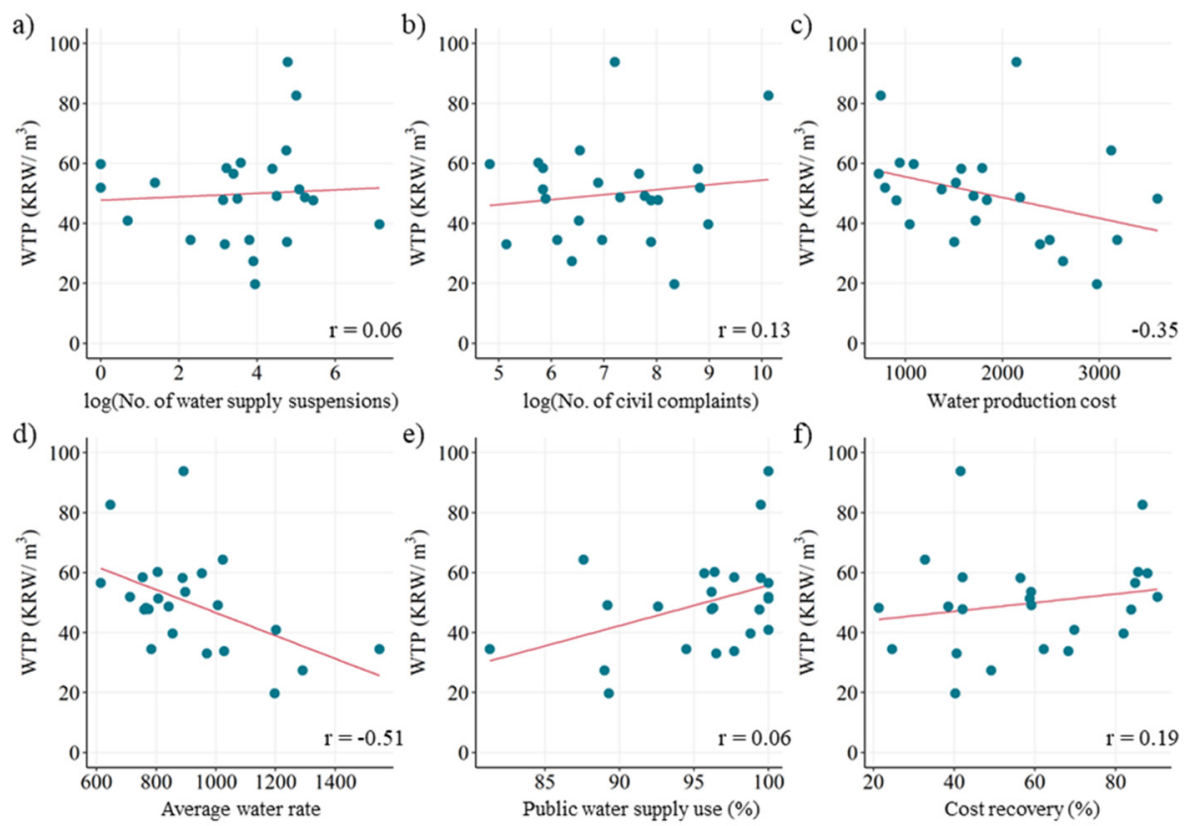

Figure 5. Correlations between county-level WTPs and water supply service performances: (a) annual number of water supply suspensions in 2018; (b) annual number of civil complaints in 2018; (c) water production cost $\left(\mathrm{KRW} / \mathrm{m}^{3}\right)$; (d) average water rate $\left(\mathrm{KRW} / \mathrm{m}^{3}\right)$; (e) public water supply use (as \% of the population); and (f) cost recovery (\%).

\section{Conclusions and Management Implications}

To evaluate improved water supply services based on the implementation of water infrastructure asset management, the WTP was estimated using the CV method. A nationwide survey including 24 counties/cities across eight provinces was conducted to elicit the WTP at both individual and county levels. The results obtained from the DBDC model indicated that at the individual level, an increased customer satisfaction with water supply services was associated with an increase in the WTP, whereas negative price perceptions led to a low WTP. Increased water rates and production costs negatively affected the WTP at the county level, which was consistent with the effect of the price perception on the individual-level WTP. Furthermore, local utilities with high water rates, production costs, and low cost recovery tended to show low service performances.

These results have crucial management implications; based on the current national financial planning for the implementation of water infrastructure asset management, 50\% of the subsidies were planned to be distributed equally among the local utilities, whereas the remaining amount would be distributed based on evaluations for service improvements. However, our results indicated that for poorly performing water utilities that tend to have 
poor financial conditions, maintaining or improving the water supply service performances was generally not feasible without government interventions. Therefore, as an alternative to the current planning, subsidies should be distributed at a rate inversely proportional to the water supply service performances of local utilities and particular importance should be given to price indicators, such as the water rates, production costs, or cost recovery. The disproportional assignment of national investments to poorly performing utilities is a prerequisite for an increasing WTP, which forms the basis for providing sustainable water supply services within the asset management framework.

Supplementary Materials: The following are available online at https://www.mdpi.com/article/10 $.3390 / w 13152040 /$ s1, Figure S1: County-level (a) mean and (b) median WTP estimated using the intercept-only DBDC model.

Author Contributions: Conceptualization, T.K.; Methodology, T.K. and J.S.; Investigation, T.K. and K.K.; Data Curation, J.S. and J.H.; Software, J.S.; Formal analysis, T.K., J.S., and Y.C.; Visualization, J.S. and Y.C.; Writing-Original Draft, T.K., J.S., and Y.C.; Writing-Review and Editing, Y.C.; Supervision, J.K. and Y.C. All authors have read and agreed to the published version of the manuscript.

Funding: This research was funded by Korea Environment Industry \& Technology Institute (KEITI) through the project for developing innovative drinking water and wastewater technologies, funded by Korea Ministry of Environment (MOE) (2020002700001).

Institutional Review Board Statement: Not applicable.

Informed Consent Statement: Not applicable.

Data Availability Statement: The data are not publicly available due to privacy issue.

Acknowledgments: The authors would like to thank the editors and reviewers for useful comments which were helpful in improving the quality of the manuscript.

Conflicts of Interest: The authors declare no conflict of interest.

\section{References}

1. Amaral, R.; Alegre, H.; Matos, J.S. Highlights of key international water infrastructure asset management initiatives, and trends, challenges and developments in Portugal. Water Policy 2017, 19, 128-146. [CrossRef]

2. Gay, L.F.; Sinha, S.K. Water Infrastructure Asset Management Primer; IWA Publishing: London, UK, 2014. [CrossRef]

3. Han, S.; Chae, M.J.; Hwang, H.; Choung, Y. Evaluation of customer-driven level of service for water infrastructure asset management. J. Manag. Eng. 2015, 31, 4014067. [CrossRef]

4. Serag, A.; Abu-Samra, S.; Zayed, T. Level of service-based asset management framework for water supply systems. J. Pipeline Syst. Eng. Pract. 2020, 11, 4020026. [CrossRef]

5. Barton, N.A.; Farewell, T.S.; Hallett, S.H.; Acland, T.F. Improving pipe failure predictions: Factors affecting pipe failure in drinking water networks. Water Res. 2019, 164, 114926. [CrossRef]

6. Barton, N.A.; Farewell, T.S.; Hallett, S.H. Using generalized additive models to investigate the environmental effects on pipe failure in clean water networks. NPJ Clean Water 2020, 3, 1-12. [CrossRef]

7. Folkman, S. Water Main Break Rates in the USA and Canada: A Comprehensive Study; Mechnical and Aerospace Engineering Faculty Publications, Utah State University: Logan, UT, USA, 2018.

8. America Water Works Aassociation (AWWA). Buried No Longer: Confronting America's Water Infrastructure Challenge; AWWA: Denver, CO, USA, 2012.

9. Choi, I.-C.; Shin, H.-J.; Nguyen, T.T.; Tenhunen, J. Water policy reforms in South Korea: A historical review and ongoing challenges for sustainable water governance and management. Water 2017, 9, 717. [CrossRef]

10. Ministry of Environment. Statistics of Waterworks 2019; MOE: Sejong, Korea, 2020.

11. Ministry of Environment. Guideline for Local Waterworks Modernization Project; MOE: Sejong, Korea, 2020.

12. Kwon, K.W. Local Waterworks Modernization Project (Aging Pipe Renewal Project); Korea Environmental Industry \& Technology Institute: Seoul, Korea, 2017.

13. Park, S.; Park, S.I.; Lee, S.-H. Strategy on sustainable infrastructure asset management: Focus on Korea's future policy directivity. Renew. Sustain. Energy Rev. 2016, 62, 710-722. [CrossRef]

14. Mizusawa, D.; McNeil, S. Generic methodology for evaluating net benefit of asset management system implementation. J. Infrastruct. Syst. 2009, 15, 232-240. [CrossRef]

15. Pearce, D. Cost benefit analysis and environmental policy. Oxf. Rev. Econ. Policy. 1998, 14, 84-100. [CrossRef] 
16. Jin Jun, H.; Park, J.K.; Ho Bae, C. Economic valuation of aging water main improvements. J. Pipeline Syst. Eng. Pract. 2020, 11, 4019053. [CrossRef]

17. Justin, M. Quantifying the benefits of Asset Management. In Proceedings of the IET and IAM Asset Management Conference, London, UK, 1 December 2011; Volume 2011, pp. 1-6.

18. Alegre, H.; Covas, D.; Monteiro, A.J.; Duarte, P. Water infrastructure asset management: A methodology to define investment prioritization. Water Distrib. Syst. Anal. Symp. 2006, 2008, 1-22.

19. Guo, D.; Wang, A.; Zhang, A.T. Pollution exposure and willingness to pay for clean air in urban China. J. Environ. Manag. 2020, 261, 110174. [CrossRef]

20. Choi, I.-C.; Kim, H.N.; Shin, H.-J.; Tenhunen, J.; Nguyen, T.T. Willingness to pay for a highland agricultural restriction policy to improve water quality in South Korea: Correcting anomalous preference in contingent valuation method. Water 2016, 8, 547. [CrossRef]

21. Tokunaga, K.; Sugino, H.; Nomura, H.; Michida, Y. Norms and the willingness to pay for coastal ecosystem restoration: A case of the Tokyo Bay intertidal flats. Ecol. Econ. 2020, 169, 106423. [CrossRef]

22. Yi, S.; Kim, S. Economic value of coastal environment improvement programs in aquaculture zones in South Korea. Ocean Coast. Manag. 2020, 195, 105277. [CrossRef]

23. Jiang, D.; Bai, D.; Yin, Z.; Fan, G. Willingness to pay for enhanced water security in a rapidly developing shale gas region in China. Water 2019, 11, 1888. [CrossRef]

24. Lee, S.; Nguyen, T.T.; Kim, H.N.; Koellner, T.; Shin, H.-J. Do consumers of environmentally friendly farming products in downstream areas have a WTP for water quality protection in upstream areas? Water 2017, 9, 511. [CrossRef]

25. Byambadorj, A.; Lee, H.S. Household willingness to pay for wastewater treatment and water supply system improvement in a Ger area in Ulaanbaatar City, Mongolia. Water 2019, 11, 1856. [CrossRef]

26. Koss, P.; Khawaja, M.S. The value of water supply reliability in California::A contingent valuation study. Water Policy 2001, 3 , 165-174. [CrossRef]

27. Tussupova, K.; Berndtsson, R.; Bramryd, T.; Beisenova, R. Investigating willingness to pay to improve water supply services: Application of contingent valuation method. Water 2015, 7, 3024-3039. [CrossRef]

28. Chatterjee, C.; Triplett, R.; Johnson, C.K.; Ahmed, P. Willingness to pay for safe drinking water: A contingent valuation study in Jacksonville, FL. J. Environ. Manag. 2017, 203, 413-421. [CrossRef]

29. Kwak, S.-Y.; Yoo, S.-H.; Kim, C.-S. Measuring the willingness to pay for tap water quality improvements: Results of a contingent valuation survey in Pusan. Water 2013, 5, 1638-1652. [CrossRef]

30. Johnston, R.; Boyle, K.; Adamowicz, W.; Bennett, J.; Brouwer, R.; Cameron, T.; Hanemann, W.; Hanley, N.; Ryan, M.; Scarpa, R.; et al. Contemporary guidance for stated preference studies. J. Assoc. Environ. Resour. Econ. 2017, 4, 319-405. [CrossRef]

31. Hanemann, W.M. Welfare evaluations in contingent valuation experiments with discrete responses. Am. J. Agric. Econ. 1984, 66, 332-341. [CrossRef]

32. Hanemann, W.M. Valuing the environment through contingent valuation. J. Econ. Perspect. 1994, 8, 19-43. [CrossRef]

33. Mitchell, R.C.; Carson, R.T. Using Surveys to Value Public Goods: The Contingent Valuation Method, 1st ed.; RFF Press: New York, NY, USA, 1989.

34. Hanemann, M.; Loomis, J.; Kanninen, B. Statistical efficiency of double-bounded dichotomous choice contingent valuation. Am. J. Agric. Econ. 1991, 73, 1255-1263. [CrossRef]

35. Ministry of Environment. Statistics of Waterworks (2018); MOE: Sejong, Korea, 2019.

36. Aadland, D.; Caplan, A.J. Willingness to pay for curbside recycling with detection and mitigation of hypothetical bias. Am. J. Agric. Econ. 2003, 85, 492-502. [CrossRef]

37. Boyle, K.J.; Bishop, R.C.; Welsh, M.P. Starting point bias in contingent valuation bidding games. Land Econ. 1985, 61, 188-194. [CrossRef]

38. Halstead, J.M.; Luloff, A.E.; Stevens, T.H. Protest bidders in contingent valuation. Northeast. J. Agric. Resour. Econ. 1992, 21, 160-169.

39. Krinsky, I.; Robb, A.L. On approximating the statistical properties of elasticities. Rev. Econ. Stat. 1986, 68, 715-719. [CrossRef]

40. R Core Team. A Language and Environment for Statistical Compution. Available online: https://www.r-project.org/ (accessed on 6 June 2021).

41. Nakatani, T.; Aizaki, H.; Sato, K. DCchoice: An R Package for Analyzing Dichotomous Choice Contingent Valuation Data. Available online: https://rdrr.io/cran/DCchoice/ (accessed on 6 June 2021).

42. Guerrini, A.; Vigolo, V.; Romano, G.; Testa, F. Levers supporting tariff growth for water services: Evidence from a contingent valuation analysis. J. Environ. Manag. 2018, 207, 23-31. [CrossRef] [PubMed]

43. Gschwandtner, A.; Jang, C.; McManus, R. Improving drinking water quality in South Korea: A choice experiment with hypothetical bias treatments. Water 2020, 12, 2569. [CrossRef]

44. Lee, C.W.; Yoo, D.G. Decision of water quality measurement locations for the identification of water quality problems under emergency link pipe operation. Appl. Sci. 2020, 10, 2707. [CrossRef]

45. Um, M.-J.; Kwak, S.-J.; Kim, T.-Y. Estimating willingness to pay for improved drinking water quality using averting behavior method with perception measure. Environ. Resour. Econ. 2002, 21, 285-300. [CrossRef] 
46. Friedman, M.; Martel, K.; Hill, A.; Holt, D.; Smith, S.; Ta, T.; Sherwin, C.; Hiltebrand, D.; Pommerenk, P.; Hinnedi, Z.; et al. Establishing Site-Specific Flushing Velocities Water Research Foundation Report Series, 1st ed.; IWA Publishing: Denver, Japan, 2004.

47. Asibey, M.O.; Dosu, B.; Yeboah, V. The roles and attitudes of urbanites towards urban water insecurity. Case of the new Juaben Municipality, Ghana. Sustain. Water Resour. Manag. 2019, 5, 2023-2036. [CrossRef]

48. Expósito, A. Valuing households' willingness to pay for water transfers from the irrigation sector: A case study of the City of Seville (Southern Spain). Sustainability 2019, 11, 6982. [CrossRef]

49. Peng, Z.; Zhang, L.; Yin, J.; Wang, H. Study of impact factors of willingness to pay regarding water reserve of South-to-North Water Diversion Project in Beijing based on Bayesian network model. J. Clean. Prod. 2018, 184, 569-578. [CrossRef] 